\title{
Praktik insider trading sebagai bentuk pelanggaran prinsip keterbukaan informasi dalam pasar modal di Indonesia
}

\author{
Fisuda Alifa Mimiamanda Radinda ${ }^{1}$, Monika Ardia Ningsi Massora ${ }^{2}$, \\ Ricka Auliaty Fathonah ${ }^{3}$
}

${ }^{1}$ Fisuda Alifa Mimiamanda Radinda; Fakultas Hukum Magister Kenotariatan Universitas Airlangga; Jalan Airlangga Nomor 4-6; Surabaya; 60286; Indonesia.

${ }^{2}$ Monika Ardia Ningsi Massora; Fakultas Hukum Magister Kenotariatan Universitas Airlangga; Jalan Airlangga Nomor 4-6; Surabaya; 60286; Indonesia.

${ }^{3}$ Ricka Auliaty Fathonah; Fakultas Hukum Magister Kenotariatan Universitas Airlangga; Jalan Airlangga Nomor 4-6; Surabaya; 60286; Indonesia.

\section{ART I CLEINFO}

Article history.

Received 2020-01-18

Received in revised form

2020-02-01

Accepted 2020-04-01

Kata kunci.

Insider Trading; Prinsip

Keterbukaan; Pasar Modal.

Keywords.

Insider Trading; Principle of

Openness; Capital Market.

DOI. https.//doi.org/10.26905/

idjch.v11i1.3528.

How to cite item.

Radinda, FAM.dkk. (2020).

Praktik insider trading sebagai

bentuk pelanggaran prinsip

keterbukaan informasi dalam

pasar modal di Indonesia. Jurnal

Cakrawala Hukum, 11(1), 41-49.

doi.10.26905/idjch.v11i1.3528.

\begin{abstract}
Abstrak
Penelitian ini membahas tentang perlindungan hukum investor terhadap praktik insider trading pada pasar modal di Indonesia dan pelanggaran/kejahatan insider trading merupakan bentuk pelanggaran dari prinsip keterbukaan informasi di dalam pasar modal. Tujuan dari penelitian ini adalah untuk menganalisis perlindungan hukum investor terhadap praktik insider trading pada pasar modal di Indonesia dan pelanggaran/kejahatan insider trading merupakan bentuk pelanggaran dari prinsip keterbukaan informasi di dalam pasar modal. Penelitian ini menggunakan metode yuridis normatif. Pendekatan yang digunakan adalah pendekatan perundangundangan. Bahan hukum yang digunakan adalah bahan hukum primer dan bahan hukum sekunder. Teknik pengumpulan bahan hukum yang digunakan melalui studi kepustakaan. Teknis analisis yang digunakan dengan logika deduktif, yaitu menarik kesimpulan dari yang bersifat umum menjadi khusus. Hasil penelitian adanya kesulitan untuk memberikan suatu perlindungan hukum terhadap Investor akibat praktik Insider Tranding, karena adanya kelemahan pada UUPM untuk penindakan praktik orang dalam atau insider trading dalam Pasar Modal dan Insider Trading merupakan bentuk pelanggaran dari prinsip keterbukaan informasi di dalam Pasar Modal, meskipun tujuan dari prinsip keterbukaan informasi itu sendiri adalah untuk menjamin transparasi di pasar modal.
\end{abstract}

\begin{abstract}
This study discusses the legal protection of investors against the practice of insider trading in the capital market in Indonesia and violations / crimes of insider trading is a form of violation of the principle of information disclosure in the capital market. The purpose of this study is to analyze the legal protection of investors against the
\end{abstract}

Corresponding Author:

* Fisuda Alifa Mimiamanda Radinda.

E-mail address: fisudaalifamimiamandaradinda84@gmail.com 


\section{Jurnal Cakrawala Hukum, Volume 11 No. 1 April 2020 \\ ISSN PRINT 2356-4962 ISSN ONLINE 2598-6538}

practice of insider trading in the capital market in Indonesia and violations / crimes of insider trading is a form of violation of the principle of information disclosure in the capital market. This research uses the normative juridical method. The approach used is the Invitation-invite approach. The legal material used is primary legal material and secondary legal material. Legal material collection techniques used through library studies. Technical analysis used with deductive logic, which draws conclusions from general to specific. The results of the study are difficult to provide a legal protection for investors due to Insider Tranding practices, due to weaknesses in the Capital Market Law for the enforcement of insider trading practices in the Capital Market and Insider Trading is a form of violation of the principle of information disclosure in the Capital Market, even though the purpose of the principle of information disclosure itself is to guarantee transparency in the capital market.

\section{LatarBelakang}

Pasar modal merupakan kegiatan yang berhubungan dengan penawaran umum dan perdagangan efek, perusahaan publik yang berkaitan dengan efek yang diterbitkannya, juga lembaga dan profesi yang berkaitan dengan efek. "Pasar modal di negara maju merupakan salah satu lembaga yang diperhitungkan bagi perkembangan ekonomi negara tersebut. Maka dari itu, negara atau pemerintah mempunyai alasan untuk ikut mengatur jalannya dinamika pasar modal" (Sitompul, 1995).

"Pasar modal merupakan sarana alternatif untuk mencari dana bagi perusahaan dan sebagai wadah investasi bagi masyarakat (investor) yang di dalamnya meliputi transaksi perdagangan efek dan penawaran umum dari perusahaan publik (emiten) kepada masyarakat investor" (Gisymar 1999). Pasal 1 angka 13 Undang-Undang Nomor 8 Tahun 1995 tentang Pasar Modal menyatakan bahwa "pasar modal adalah kegiatan yang bersangkutan dengan penawaran umum dan perdagangan efek, perusahaan publik yang berkaitan dengan efek, serta lembaga dan profesi yang berkaitan dengan efek. Kegiatan pasar modal tersebut telah dilindungi oleh payung hukum yang sangat menjunjung tinggi prinsip keterbukaan."

Prinsip keterbukaan informasi Pasal 1 angka 25 Undang-Undang Pasar Modal (UUPM) menya- takan, "prinsip keterbukaan informasi merupakan pedoman umum yang mensyaratkan emiten, perusahaan publik, dan pihak lain yang tunduk pada undang-undang ini untuk menginformasikan kepada masyarakat dalam waktu yang tepat seluruh informasi material mengenai usahanya atau efeknya yang dapat berpengaruh terhadap keputusan pemodal terhadap efek dimaksud dan/ atau harga dari efek tersebut".

Perdagangan efek yang wajar yaitu kegiatan perdagangan yang mana berlangsung secara alamiah, maksudnya setiap kekuatan permintaan atau penawaran yang dilakukan sesuai mekanisme pasar yang bebas dari adanya keadaan yang tidak mendukung timbulnya keadaan pasar sesuai dengan harapan dari para pelakunya, misalnya terdapat sistem penyampaian informasi yang akurat dan tepat waktu dari emiten, terhindarnya pasar dari pihak tertentu untuk memperoleh keuntungan dari ketidaktahuan pihak lainnya dan adanya sistem juga tata cara pelaksanaan perdagangan yang mendukung timbulnya kewajaran di dalam melakukan perdagangan bursa efek (Gisymar, 1999).

Keterbukaan informasi merupakan mekanisme yang ditujukan kepada tiga pihak utama, yaitu emiten, investor dan perantara di pasar modal (market intermediaries). Untuk emiten, kewajiban keterbukaan harus dipatuhi untuk 


\section{Praktik insider trading sebagai bentuk pelanggaran prinsip keterbukaan informasi dalam pasar modal di Indonesia \\ Fisuda Alifa Mimiamanda Radinda, Monika Ardia Ningsi Massora, Ricka Auliaty Fathonah}

menjamin efisiensi pasar, sedangkan bagi investor, keterbukaan informasi digunakan untuk pengambilan keputusan investasi investor (informed decisions). Sementara untuk perantara di pasar modal seperti analis atau penasihat investasi, perantara perdagangan Efek atau pialang, manajer investasi atau perantara lainnya, ada kewajiban untuk secara bertanggung jawab mencerna, menyaring dan memberikan pendapat atas informasi yang disajikan dalam dokumen keterbukaan informasi. Hal ini dikarenakan sebagian besar pelaku pasar sangat tergantung pada kemampuan para perantara pasar modal untuk menjelaskan dan mengungkapkan data keterbukaan yang kompleks dan menyampaikan pendapat nasihat investasi berdasarkan keahlian mereka (Rahmah, 2019).

Memberikan perlindungan hukum untuk investor adalah menjadi hal yang krusial dalam investasi dan dunia bisnis, wujud dari perlindungan hukum itu berupa legal substance dan legal structure dimana keduanya saling berkaitan dalam memberi perlindungan hukum dan kepastian. Pembuktian praktik insider trading di pasar modal cukup sulit disebabkan tidak mudah untuk menentukan standar fakta materiel dalam prinsip keterbukaan informasi. Selain itu perangkat hukum tidak ada kejelasan pengaturan dalam UUPM atas perlindungan hukum dari praktik insider trading. Tidak adanya perlindungan hukum untuk investor terhadap kejahatan insider trading di pasar modal maka akan terjadi unfair market, illicit profit, dan untrustable market yang merugikan investor.

\section{Metode}

Penelitian hukum (Legal research) adalah kegiatan ilmu hukum dalam rangka menemukan dan menciptakan hukum serta memecahkan isu hukum yang dihadapi dengan mengunakan identiffikasi dan penalaran hukum (Marzuki, 2014).

Penelitian ini menggunakan yuridis normatif dikarenakan dalam penelitian ini dibutuhkan kajian terhadap sumber-sumber hukum yang mengatur tentang insider trading dan prinsip keterbukaan informasi dalam Pasar Modal di Indonesia. Adapun Penelitian ini menggunakan Pendekatan Peraturan Perundang- Undangan (statute approach) yaitu pendekatan yang mana menelaah undangundang dan regulasi yang berkaitan dengan isu hukum yang dibahas, dengan menggunakan sumber bahan hukum yaitu, sumber bahan hukum primer dan bahan hukum sekunder.

Pengumpulan dan pengolahan bahan hukum dalam penelitian ini dilakukan dengan cara mengidentifikasi fakta hukum dan memilah hal-hal yang tidak relevan dalam menetapkan isu hukum, pengumpulan bahan-bahan hukum dan sekiranya dipandang mempunyai relevansi bahan-bahan non hukum, melakukan telaah atas isu yang diajukan berdasarkan bahan-bahan yang telah dikumpulkan, menarik kesimpulan dalam bentuk argumentasi yang menjawab isu hukum, memberikan preskripsi berdasarkan argumentasi yang telah dibangun di dalam kesimpulan (Marzuki, 2005).

\section{Pembahasan}

\subsection{Perlindungan hukum investor terhadap praktik insider trading pada pasar modal di Indonesia}

UUPM meletakkan suatu kewajiban kepada Negara untuk melindungi investor dari praktikpraktik insider trading yang sangat dimungkinkan terjadi dalam pasar modal Indonesia. Apabila dilihat dari segi yuridis, dalam hal ini UUPM kurang mendukung dalam melindungi investor, karena pengaturan dalam UUPM belum menganut teori penyalahgunaan (misappropriation theory) dan hanya menganut teori hubungan kepercayaan ( $f i-$ duciary duty theory) sehingga apabila terjadi praktik perdagangan orang dalam (insider trading) maka diberikan sanksi hukum kepada orang dalam insider trading tersebut. "Prinsip keterbukaan sangatlah penting, adapun tujuannya adalah untuk melin- 


\section{Jurnal Cakrawala Hukum, Volume 11 No. 1 April 2020}

ISSN PRINT 2356-4962 ISSN ONLINE 2598-6538

dungi kepercayaan investor, ketika muncul ketidakpercayaan terhadap pasar modal mengakibatkan pelarian modal (capital flight) secara besar-besaran dan dapat mengakibatkan kehancuran Pasar Modal" (Sinaga, 2014).

"Teori penyalahgunaan (misappropriation theory) menyatakan setiap orang yang memakai inside information atau informasi yang belum tersedia untuk umum dan melakukan perdagangan saham atas informasi tersebut dapat dikategorikan sebagai insider. Meskipun orang yang melakukan perdagangan itu tidak mempunyai fiduciary duty dengan perusahaan (Fuadi, 1996). Pasal 95 UUPM berbunyi. "Orang dalam dan Emiten atau Perusahaan Publik yang mempunyai informasi orang dalam dilarang melakukan pembelian atau penjualan atas efek". 1. Emiten atau Perusahaan Publik dimaksud;dan 2. Perusahaan lain yang melakukan transaksi dengan Emiten atau Perusahaan Publik yangbersangkutan".

"Jika Pasal 95 dicermati mendalam, masih ada celah hukum yang dipakai oleh orang dalam (insider) ataupun orang luar yang mendapat informasi (insider) untuk melakukan transaksi efek yang dilarang atau disebut juga dengan insider trading. Pasal 95 UUPM hanya menjangkau orang dalam kapasitas fiduciary duty theory, maka dari itu para pelaku yang masuk dalam kategori misappropriation theory dapat dipastikan terhindar dari Pasal 104 UUPM yang dapat dikenakan sanksi bagi pelaku insider trading"(Gisymar, 1999).

Perlindungan hukum bagi investor akibat adanya praktik insider trading yaitu melalui penegakan hukum insider trading itu sendiri yang ada di dalam Pasar Modal. Terdapat 3 hal penegakan hukum yang ada di insider trading, yaitu penegakan secata perdata, pidana, dan administratif. "UUPM telah meletakkan landasan untuk memberikan perlindungan hukum dalam pelanggaran pasar modal yaitu . 1. Sanksi pidana (Pasal 103UUPM), 2. Tuntutan ganti kerugian secara perdata (Pasal 111UUPM), dan 3. Sanksi administratif (Pasal
102UUPM). Ketiga pasal tersebut digunakan untuk menggugat pelaku insider trading, setidaknya dapat menghindarkan beban kerugian yang telah ditanggung pihak yang dirugikan yang disebabkan adanya insider trading tersebut" (Sinaga, 2014).

Penegakan hukum insider trading terhadap kejahatan konvensional berbeda dengan penegakan hukum white collar crime. Pada kenyataannya kasus white collar crime sampai ke pengadilan jauh lebih sulit dari pada membawa kasus konvensional (Fuadi, 1996). "Faktor-faktor hal tersebut disebabkan oleh. 1. Modus operandi dari white collar crime jauh lebih rumit dibandingkan dengan kejahatan konvensional. 2. Pelaku kejahatan konvensional umumnya memiliki riwayat hidup kriminal dari pada pelaku white collarcrime. 3. Kerugian kejahatan konvensional lebih jelas dari pada kerugian white collarcrime. dan 4. Pelaku white collar crime seperti penjahat yang tidak kelihatan seperti orang-orang innoncent karena umumnya merupakan orang-orang terdidik."

Penegakan hukum pada prakteknya diarahkan ke dalam sistem hukum lain, dalam UUPM digunakan oleh anglo saxon, maka dari itu faktor dominan hakim sebagai pembentuk hukum menjadi sangat besar. Penemuan hukum dengan bebas dapat dipergunakan untuk menangani kasus insider trading dikarenakan penemuan hukum itu bebas dapat dilakukan dengan cara menganggap undang-undang sebagai alat bantu untuk memperoleh pemecahan yang tepat menurut hukum dan penyelesaiannya tidak sama dengan undangundang. "Penemuan hukum dapat bebas digunakan dimaksudkan menciptakan penyelesaian yang tepat bukan untuk menerapkan hokum. Namun untuk peristiwa nyata sehingga peristiwa berikutnya dapat dipecahkan menurut kaidah yang telah diciptakan oleh hakim" (Sinaga, 2014).

Dalam hal ini adanya peran dari OJK merupakan inti dari penegakan hukum pasar modal. Karena apabila terdapat pelanggaran yang ada pada UUPM yang berupa manipulasi pasar, keja- 


\section{Praktik insider trading sebagai bentuk pelanggaran prinsip keterbukaan informasi dalam pasar modal di Indonesia}

Fisuda Alifa Mimiamanda Radinda, Monika Ardia Ningsi Massora, Ricka Auliaty Fathonah

hatan penipuan, misleading information dan insider trading, dalam hal ini OJK berwenang penuh untuk menyelesaikan. Pasal 105 UUPM menyatakan bahwa, penyidik PNS harus menyampaikan kapan dimulai dan kapan diberhentikannya penyidikan kemudian menyampaikan hasil penyidikannya kepada penuntut umum supaya tidak bertentangan dengan Kitab Undang-Undang Hukum Acara Pidana. Pasal 101 ayat 6 dan penjelasannya bahwa "penyidik PNS di lingkungan OJK yang melakukan penyidikan terhadap kasus kejahatan Pasar Modal dapat meminta bantuan kepada Jaksa Agung, aparat Kepolisian, Kementerian Hukum dan HAM, Dirjen Imigrasi." Berikut adalah keuntungan transformasi fungsi dan wewenang BAPEPAM-LK kepada OJK. (USU, 2013)

1. "Meningkatkan efektifitas pengawasan yaitu terhadap produk hybrid di lembaga keuangan."

2. "Meningkatkan efisiensi yang dilakukan oleh OJK yaitu efisiensi antar lembaga yang memiliki latar belakang aturan yang berbeda, termasuk juga peningkatan skala ekonomi. Dari segi intern pemerintah, dengan terbentuknya lembaga ini akan membuat pembiayaan terhadap lembaga ini menjadi optimal dan akan semakin meningkat. Dari segi eksternal, akan mendapat kemudahan akses terhadap lembaga tersebut. Dengan pelayanan satu atap akan dapat memperbaiki pelayanan kepada pihakpihak yang berhubungan dengan jasa keuangan dan juga menyederhanakan birokrasi. Maka dari itu, diharapkan dengan adanya keberadaan OJK diharapkan akan menyederhanakan birokrasi yang ada."

3. "Meningkatkan perlindungan hukum bagi investor."

\subsection{Pelanggaran/kejahatan insider trading merupakan bentuk pelanggaran dari prinsip keterbukaan informasi di dalam pasar modal}

Pelanggaran atau kejahatan yang dilakukan di pasar modal akan berdampak secara luas dan tidak terputus, maksudnya berdampak bukan hanya pada broker dan investor saja, namun juga berdampak pada perusahaan yang efeknya diperdagangkan. Karena hal ini termasuk mempengaruhi investor ataupun masyarakat publik dalam mengambil keputusan apakah membeli saham atau menjualnya. Justru ini adalah hal yang sangat merugikan beberapa pihak di pasar modal.

Perdagangan orang dalam diidentikkan dengan kasus pencurian. "Perbedaannya dengan pencurian konvensional yaitu pada pencurian konvensional objeknya merupakan materi kepunyaan orang lain, sedangkan pada perdagangan orang dalam objek pencurian tetap milik orang lain, namun dengan menggunakan informasi yang seharusnya milik umum, sehingga dengan menggunakan informasi tersebut pelaku dapat memperoleh keuntungan." "Pencurian konvensional, yang mengalami kerugian adalah pihak pemilik barang, sedangkan pada kasus perdagangan orang dalam, yang mengalami kerugian begitu banyak dan meluas, mulai dari lawan transaksi, hingga kepada kewibawaan regulator dan kredibilitas pasar modal. Kalau kredibilitas sudah sirna, maka kepercayaan masyarakat terhadap pasar modal juga akan berkurang" (Nasarudin dan Indra, 2004).

Menurut Pasal 1 angka 7 UUPM "Informasi material adalah informasi atau fakta penting dan relevan mengenai peristiwa, kejadian, atau fakta yang dapat mempengaruhi harga Efek pada Bursa Efek dan atau keputusan pemodal, calon pemodal, atau Pihak lain yang berkepentingan atas informasi atau fakta tersebut".

Fungsi keterbukaan informasi.

1. Sebagai alat untuk menekan atau mengontrol biaya Sebagai instrumen untuk mengontrol biaya transaksi, keterbukaan dapat mengurangi biaya atas modal dan meningkatkan efisiensi di pasar modal. Keterbukaan yang terstandarisasi dan seragam akan mengurangi biaya transaksi terkait dengan penawaran Efek seperti biaya penerbitan Efek, biaya pembuatan perjanjian untuk penerbitan Efek, ter- 


\section{Jurnal Cakrawala Hukum, Volume 11 No. 1 April 2020}

ISSN PRINT 2356-4962 ISSN ONLINE 2598-6538

masuk biaya untuk penyelesaian transaksi nantinya.

2. Sebagai alat untuk mengatur

Keterbukaan informasi digunakan sebagai mekanisme untuk memenuhi persyaratan yang ditetapkan peraturan perundang- undangan. Regulator pasar modal menetapkan kewajiban keterbukaan informasi untuk menilai kelayakan emiten dalam menawarkan Efek di pasar perdana. Keterbukaan informasi juga merupakan instrumen pengaturan untuk memberikan sanksi bagi pelanggar serta mengeluarkan pelaku pasar modal yang melanggar keterbukaan dengan mencabut izinnya. Keterbukaan informasi menjadi alat untuk mengarahkan pelaku pasar modal agar sesuai dengan pedoman yang ditetapkan.

3. Sebagai alat untuk pengelolaan

Keterbukaan memiliki fungsi tata kelola perusahaan yang menunjukkan dan mengomunikasikan pesan ke pelaku pasar modalterkait dengan efektivitas pengelolaan perusahaan emiten. Keterbukaan menjadi alat yang menunjukkan kepada investor tentang efisiensi operasional, pengawasan direktor, dan keterampilan manajerial (Rahmah, 2019).

Menurut Yulsafni unsur-unsur dari insider trading, yaitu. (Yulsafni, 2005) "Terdapat orang dalam; Informasi material yang belum disclosure; Melakukan transaksi karena informasi material; Mendapatkan keuntungan yang tidak layak (illicitprofit)."

Keberadaan praktik insider trading ini menimbulkan terjadinya ketidakadilan informasi yang hanya dapat diperoleh oleh sejumlah orang tertentu saja dengan tujuan untuk mendapat keuntungan yang sebenarnya bukan haknya. Hal ini bertentangan dengan prinsip keterbukaan yang diatur dalam Pasal 48 ayat (1) dan Pasal 95 UUPM, yang memberikan persyaratan bahwa setiap pelaku pasar modal dalam setiap penawaran sahamnya harus memuat informasi material yang benar dan tidak memberikan gambaran yang menyesatkan. Semakin banyaknya pelaku pasar modal tidak menutup kemungkinan adanya pelanggaran yang akan dilakukan oleh pelaku pasar modal atas aturan pasar modal yang ada. "Timbulnya pelanggaran terhadap aturan main dalam transaksi efek disebabkan karena lemahnya sistem pengawasan yang dilakukan oleh pihak pengelola bursa dan juga pengawas bursa sehingga apabila terjadi pelanggaran transaksi efek baik karena insider trading ataupun manipulasi informasi yang menyesatkan akan sulit untuk terdeksi" (Fuady, 2001).

Pasal 95 dan Pasal 96 UUPM membagi larangan bagi orang dalam untuk melakukan transaksi efek menjadi tiga, yaitu.

1. "Larangan untuk orang dalam melakukan pembelian/penjualan atas Efek Emiten atau Perusahaan Publik yang bersangkutan didasarkan atas pertimbangan bahwa kedudukan orang dalam seharusnya mendahulukan kepentingan Emiten, Perusahaan Publik, atau pemegang saham termasuk untuk tidak menggunakan informasi orang dalam untuk kepentingan diri sendiri atau Pihak lain."

2. "Orang dalam yang telah disebutkan dalam Pasal 95 dilarang untuk mempengaruhi Pihak lain melakukan pembelian dan atau penjualan atas Efek dari Emiten atau Perusahaan Publik yang bersangkutan, meskipun orang dalam dimaksud tidak memberikan informasi orang dalam kepada Pihak lain, karena hal ini dapat mendorong Pihak lain untuk melakukan pembelian atau penjualan Efek berdasarkan informasi orang dalam itu sendiri. "

3. "Orang dalam dilarang memberikan informasi kepada Pihak lain yang patut diduga akan menggunakan informasi tersebut untuk melakukan pembelian atapun penjualan Efek. Dengan demikian orang dalam mempunyai kewajiban untuk berhati-hati dalam menyebarkan informasi agar informasi tersebut tidak disalahgunakan oleh Pihak yang menerima 


\section{Praktik insider trading sebagai bentuk pelanggaran prinsip keterbukaan informasi dalam pasar modal di Indonesia \\ Fisuda Alifa Mimiamanda Radinda, Monika Ardia Ningsi Massora, Ricka Auliaty Fathonah}

informasi tersebut untuk melakukan pembelian atau penjualan atas Efek."

Tujuan prinsip keterbukaan informasi untuk menjamin transparasi di pasar modal dalam rangka memfasilitasi terbentuknya harga yang wajar serta menyediakan informasi untuk pelaku dan otoritas pasar. Keterbukaan informasi bertujuan menjamin tersedianya informasi secara akurat dan lengkap secara tepat waktu sehingga investor memiliki pilihan untuk menetapkan investasinya berdasarkan pada informasi yang terkait dengan aktivitas emiten atau perusahaan publik. Oleh karena itu keterbukaan informasi diharapkan dapat meningkatkan efisiensi dan efektivitas pasar karena dapat menjamin penyebaran informasi materiel untuk pelaku pasar. "Keterbukaan informasi sangat penting bagi terwujudnya pasar yang efisien dan adil, mengurangi risiko investasi dan berfungsi sebagai mekanisme untuk melindungi investor" (Rahmah, 2019).

Keterbukaan informasi sangat diperlukan karena informasi merupakan hal yang penting untuk mengambil keputusan investasi pemodal. Dalam memutuskan membeli atau menjual Efek, pemodal mengambil keputusan investasi berdasarkan pada informasi yang tersedia (informed decision). Informed decision menentukan harga pasar yang wajar. Harga pasar yang wajar harus bisa direfleksikan nilai instrinsik Efek. Nilai instrinsik Efek tergantung dari seberapa efisien tersedianya informasi dari perusahaan yang bersangkutan (Munir Fuadi, 1996).

Kewajiban keterbukaan informasi untuk emiten dan Perusahaan Publik diatur dalam Pasal 86 ayat (1) UUPM, yaitu.

a. memberikan laporan secara berkala kepada Bapepam dan mengumumkan laporan tersebut kepada masyarakat; dan

b. memberikan laporan kepada Bapepam dan mengumumkan kepada masyarakat tentang peristiwa material yang dapat mempengaruhi harga Efek selambat-lambatnya pada akhir hari kerja ke-2 (kedua) setelah terjadinya peristiwatersebut.

Sedangkan kewajiban keterbukaan informasi untuk pihak lain diatur dalam Pasal 87 yaitu.

a. Direktur atau komisaris Emiten atau Perusahaan Publik wajib melaporkan kepada Bapepam atas kepemilikan dan setiap perubahan kepemilikannya atas saham perusahaan tersebut;

b. Setiap Pihak yang memiliki sekurang-kurangnya 5\% (lima perseratus) saham Emiten atau Perusahaan Publik wajib melaporkan kepada Bapepam atas kepemilikan dan setiap perubahan kepemilikannya atas saham perusahaan tersebut.

Menurut seorang pakar di bidang keuangan, insider trading ini dikategorikan sebagai masalah jika memenuhi unsur tertentu. Unsur tersebut adalah unsur penipuan (fraud atau deceit). Pendapat Michael Rozeff, Profesor dari University of Iowa yang banyak menulis tentang insider trading, menyimpulkan bahwa insider trading merupakan topik yang kontroversial dan belum ada kesepakatan tentang ini. Menurutnya, sebagian besar dari para investor menerima insider trading sebagai suatu kenyataan. Insider trading akan menarik perhatian masyarakat setelah melewati berita yang spektakuler tentang kasus insider trading di media massa (Rozeff, Michael S. and Zaman, 1988).

Terdapat dua pendapat yang saling bertentangan yaitu menurut $\mathrm{H}$. Manne dan U Bhattacharya. Pendapat pertama diungkap oleh H. Manne yang memaparkan hal tentang insider trading sebagai berikut (H. Mame, 1966). "Insider trading provides an incentive for entrepreneurial activity, and that it enhances market efficiency through the faster dissemination of information". Artinya bahwa insider trading memberikan satu insentif bagi kegiatan kewirausa- 


\section{Jurnal Cakrawala Hukum, Volume 11 No. 1 April 2020}

ISSN PRINT 2356-4962 ISSN ONLINE 2598-6538

haan yang dapat meningkatkan efisiensi pasar melalui informasi yang cepat tersebar.

Sedangkan U Bhattacharya dan $\mathrm{H}$ Daouk berpendapat sebagai berikut (Bhattacharya, U. 2002). "Recently, empirical studies have also found that the proper enforcement of insider trading laws reduces the cost of equity capital by about $5 \%$, which suggest that any advantage from a market efficiency perspective is outweighed by the loss of investor confidence caused by insider trading" Artinya, berdasarkan studi empiris terkini didapat bahwa penegakan hukum terkait kasus insider trading akan mengurangi biaya modal kira-kira 5\%, keuntungan lain dari tindakan tersebut adalah efisiensi pasar tercapai sekaligus tingkat kepercayaan investor akan meningkat.

Pendapat kedua ini banyak mendapat dukungan karena perlindungan bagi investor lebih kuat. "Terdapat tiga hal penting yang akan dicapai jika penegakan hukum terhadap kasus insider trading diterapkan," yaitu (Bhattacharya, 2002).

1. "Menerapkan regulasi yang efektif dibidang hukum khususnya penegakan hukum secara umum akan menghasilkan pasar modal yang lebih berkembang dan menuju ke arah yang lebih baik sekaligus memberikan perlindungan untuk investor";

2. "Menerapkan regulasi yang efektif akan membentuk siklus keterkaitan antara investor dan perusahaan publik yang lebih positif di mana dengan tingkat risiko yang rendah akan mencapai biaya operasional yang rendah juga yang pada akhirnya akan menarik perusahaanperusahaan untuk menjadi perusahaan publik yang terdaftar di pasar modal";

3. "Para regulator dan badan yang menangani penegakan hukum di pasar modal harus mampu mendeteksi dan juga mencegah tindakantindakan yang dapat merugikan investor. Apabila investor kehilangan kepercayaan pada pasar modal, maka pasar modal akan masuk pada siklus negatif di mana nilai saham akan jatuh, perusahaan-perusahan publik yang masuk dalam kategori baik juga akan keluar dari pasar modal dan pada akhirnya aktivitas pasar modal secara keseluruhan akan terhenti".

Pelanggaran terhadap prinsip keterbukaan masih banyak terjadi dalam pasar modal. Insider trading merupakan salah satu bentuk pelanggaran terhadap prinsip keterbukaan tersebut. Pada prinsipnya tujuan utama pelaku insider trading yaitu untuk mendapat keuntungan namun keuntungan di sini adalah keuntungan yang tidak diperkenankan karena informasi tersebut hanya didapat oleh beberapa orang saja. Tentunya informasi yang hanya didapat oleh beberapa orang tersebut tidak adil untuk orang yang lainnya, maka dari itu disebut dengan keuntungan yang tidak diperkenankan.

Padahal tujuan pelaksanaan prinsip keterbukaan itu sendiri adalah untuk menjamin transparasi di pasar modal dalam rangka memfasilitasi terbentuknya harga yang wajar serta menyediakan informasi untuk pelaku dan otoritas pasar. Antara prinsip keterbukaan informasi dengan insider trading memang sangat berkaitan. Dengan adanya prinsip keterbukaan informasi seharusnya dilaksanakan dengan tepat agar dapat pula melindungi kepentingan para investor dan tidak adanya pelanggaran insider trading.

\section{Simpulan}

Perlindungan hukum untuk investor terhadap Praktik Insider Trading pada Pasar Modal, yaitu sangatlah sulit untuk memberikan suatu perlindungan hukum terhadap Investor akibat praktik Insider Tranding, karena adanya kelemahan pada UUPM untuk penindakan praktik orang dalam atau insider trading dalam Pasar Modal di Indonesia, sebagaimana yang telah kita cermati dan bandingkan di beberapa negara mengenai peraturan perundangan pasar modal terus direvisi, 


\section{Praktik insider trading sebagai bentuk pelanggaran prinsip keterbukaan informasi dalam pasar modal di Indonesia}

Fisuda Alifa Mimiamanda Radinda, Monika Ardia Ningsi Massora, Ricka Auliaty Fathonah

karena dunia pasar modal sangat kompleks. Berikut ini adalah kelemahan UUPM untuk menjadi acuan pembelajaran atau memperbaiki struktur Hukum Pasar Modal Indonesia.

Pelanggaran/kejahatan Insider Trading merupakan bentuk pelanggaran dari prinsip keterbukaan informasi di dalam Pasar Modam. Meskipun tujuan dari prinsip keterbukaan informasi itu sendiri adalah untuk menjamin transparasi di pasar modal, bukan berarti bahwa prinsip keterbukaan informasi tidak dapat disalahgunakan dengan orang dalam (insider trading) ini. Orang dalam (insider trading) dapat mengakibatkan kerugian bagi para investor.

\section{Daftar pustaka}

Bhattacharya, U., and H. Daouk. 2002. The World Price of Insider Trading. Journal of Finance 57.

Fuadi, Munir. 1996. Doktrin-Doktrin Modern Dalam Corporate Law dan Eksistensinya Dalam Hukum Indonesia. Bandung. Citra Aditya Bakti.

Fuady, Munir. 2001. Pasar Modal Modern. Tinjauan Hukum. Bandung. Citra Aditya Bakti.

Gisymar, Najib A. 1999. Insider Trading dalam Transaksi Efek. Bandung. Citra Aditya Abadi.

Mame, H. 1966. Insider Trading and the Stock Market. New York. The Free Press.
Marzuki, Peter Mahmud. 2005. Penelitian Hukum. Jakarta. Kencana.

Marzuki, Peter Mahmud. 2014. Penelitian Hukum (Edisi Revisi). Jakarta. Prenadamedia Group. Rozeff.

Michael, S. and Zaman, Mir A. 1988. Market Efficiency and Insider Trading. Journal Of Business.

Nasarudin, M. Irsan dan Surya Indra. 2004. Aspek Hukum Pasar Modal Indonesia. Jakarta. Kencana.

Rahmad, Mas. 2019. Hukum Pasar Modal. Jakarta. Kencana.

Raytiaputri, R. (2016). Perkecualian terhadap prinsip larangan pembatasan kuota impor terkait penanaman modal di Indonesia. Jurnal Cakrawala Hukum, 7(1), 98-111. doi:10.26905/idjch.v7i1.1785.

Sinaga, Sare Intan A. 2014. Tinjauan Yuridis Terhadap Praktik Insider Trading Dalam Pasar Modal Indonesia. Law Jurnal. V. II No. 2. Fakultas Hukum Pekanbaru Riau I.USU.

Sitompul, Asril. 1995. Pasar Modal Penawaran Umum dan Permsalahannya. Bandung. Citra Aditya Abadi.

Yulsafni. 2005. Hukum Pasar Modal. Jakarta. Alam.

Zazili, A., Fathoni, F., \& Firmansyah, A. (2016). Pemberian insentif penanaman modal sebagai upaya daya tarik investasi di daerah. Jurnal Cakrawala Hukum, 7(1), 112-122. doi:10.26905/idjch.v7i1.1786. 